https://doi.org/10.18485/iipe_60nam.2021.ch2

\title{
JOSIP BROZ TITO AND THE BEGINNINGS OF THE NON-ALIGNED MOVEMENT
}

\author{
Ljubodrag DIMIĆ1
}

\begin{abstract}
In the present paper, the author examines the evolution of the foreign policy orientation of socialist Yugoslavia at the very beginning of the creation of the Non-Aligned Movement. The analysis uses primary and secondary sources, based on which it can be concluded that the foreign policy stance of Yugoslavia in the time of Josip Broz Tito had a clear ideological basis to answer the key problems of the then world. At the same time, Yugoslavia had the political power to actively and peacefully take over the role of a leader in a movement whose outlines were only in sight at the time of the Belgrade Summit of non-aligned countries. At that moment, non-alignment seemed to the author to be "politics with the future".
\end{abstract}

Key words: Yugoslavia, Josip Broz Tito, the Non-Aligned Movement, foreign policy.

\section{Introduction}

In September 1961, the Yugoslav State and Party leadership viewed the future with optimism. Both the East and the West respected Yugoslavia's borders and its territorial integrity and tolerated its foreign policy, albeit somewhat begrudgingly. What was the essence of this foreign policy with regard to Asia and Africa? Judging by Josip Broz Tito's political speeches and statements, Yugoslavia's foreign policy posture, which possessed clear ideological bias, was founded on several important premises:

- That the belief in the ability of the Great Powers to find a peaceful solution to the key problems of the post-war world was a delusion;

${ }^{1}$ Academician of the Serbian Academy of Sciences and Arts, Belgrade.

E-mail: ljubodrag_dimic@yahoo.com 
- That it was erroneous to dismiss "small" and especially "non-engaged" countries as incapable of participating in World politics and contributing to the resolution of international problems.

- That the fate of the world is universal (everyone would bear the consequences of a clash between the Great Powers) and that as a consequence "large" and "small" countries share a deep common interest, obligations and responsibilities.

- That conservative regimes have no future, that their time has run out and that the true aims of the armament race and the Cold war were to stop the defeat of capitalism and the spreading of socialism ("...the triumphant march of progress and world transformation..." in Tito's words) by the use of military force.

- Those international relations should be viewed realistically in the age of nuclear weapons, space exploration, accelerated technological development, scientific achievements and unprecedented life opportunities.

- That the concentrated efforts should be directed towards the triumph of "permanent peace" over the catastrophe caused by a war between the Great Powers. These principles represented the foundation of the policy of "coexistence" (peaceful and active) which implied more than a bare acknowledgement of other countries' existence. It represented a template for international relations based on lasting norms and principles, including non-interference into internal affairs of other countries, empowering nations to decide their domestic and foreign policy, opposition to aggressive wars and spheres of interest, promotion of peaceful political, economic and cultural cooperation irrespective of the political system (Tito, 1955, 1959, 1962; AJ, KPR, 837, 1960, 1961).

The policy of Non-Alignment, whose main proponents gathered in Belgrade in September 1961, was not an abstract concept. It was directly influenced by the direction of international relations. The sources of the philosophy of Non-Alignment were in the process of decolonisation and struggle for development. At the same time, Non-Alignment represented a response to the prevalent characteristic of the international relations marked by the presence of military blocs and consequent divisions as well as the resultant politics of force. The opposition to the division of the world into power blocs was the signature characteristic of the policy of Non-Alignment. This was based on the estimate that world peace would be endangered for as long as the politics of force and the existence of blocs were present and as long as the powerful countries were allowed to impose their will on the weaker ones. Siding with one of the blocs would represent an abrogation of 
the newly won sovereign rights, independent political course, active participation in international politics, cooperation with other peaceful countries and tailoring policies to suit their own interests (Bogetić, 1981, 1990; Mates, 1970; Vestad, 2009).

Anti-colonial revolutions made the Non-Aligned Movement possible. The striving for independence vis-a-vis foreign policy that emerged from these revolutions was superseded by the need for regional coming together for the purpose of a common foreign policy posture. This regionalism was eventually challenged by the universal significance of the problems that needed to be tackled. The policy gradually changed from individualism to regionalism to universalism. This process was assisted by the political principles which developed over a number of years within certain Asian countries. These principles were articulated by the Bandung Conference held in April 1955 and affirmed by all subsequent meetings of the leaders of the Non-Aligned countries. Unanimous demands for a radical change in international relations - characterised by the Cold War polarisation, economic inequality and nuclear holocaust threat - were made from the very beginning. Awareness that active participation on the international scene strengthened the independence of individual countries and made them an important factor in international political and economic relations did not immediately result in coordinated joint action. The main obstacle lay in the differences between individual countries' interests which, as would transpire later, were difficult to overcome. The universal validity of the principles of Non-Alignment was not always sufficient to heal divisions and resolve conflicts. The right of these countries to be treated as equals in tackling international problems was not granted but wrested through struggle. This was demonstrated by the Initiative of Five (Nehru, Nkrumah, Nasser, Sukarno and Tito) submitted to the UN General Assembly in September 1960, which demanded that the leaders of the US and the USSR restore their contacts and find solutions for the pressing problems through negotiations. The Belgrade Conference represented a concrete application of the right to equitable participation in solving international problems. (Bogetić, 1981, 1990; Mates, 1970; Vestad, 2009).

\section{The Yugoslav policy of peaceful and active coexistence}

Several factors critically influenced the formulation of the Yugoslav policy of "peaceful and active coexistence". Experience gained through an indigenous revolution had a direct impact on the idiosyncrasies of domestic 
political developments and international activities. Conflict with the Soviet Union and members of the Cominform forced the leadership to abandon old priorities and define new foreign policy aims. According to the judgment of the Communist Party leadership, the cooperation with the West, although grudging, represented the only way of protecting the country from the pressures coming from the Soviet Union and "Popular democracies". Additional incentives for cooperation were provided by the dire economic situation caused by the blockade, a large military budget, poor harvests (especially in 1951) and general poverty. The real prospect of the attack forced Yugoslavia to "tone down" its foreign policy, abandon the revolutionary rhetoric and draw closer to the West. Although "not conditional on political concessions", this unequal collaboration with the West bothered Tito. Steps such as the liberalisation of the economy, change in the principles of social development, switch from the heavy to light industry, the democratisation of governance, and a diminished role for the League of Communists of Yugoslavia as well as the gradual rapprochement with, and the inclusion into the Western military alliance - all of this fundamentally meant abandoning socialist principles. In the opinion of Tito and the Yugoslav leadership, finding a political alternative and a new international direction would provide a way out of the deadly embrace of the East and the West, which brought into question the survival of the country and the Communist Party rule. The knowledge gained about developments in Asia, Africa and Europe contributed greatly to the charting of this new course (Bogetić, 2000; Bekić, 1988; Gavranov and Stojković, 1972; Jovanović, 1985; Jakovina, 2002; Krempton, 2003; Laker, 1990; Petković, 1985; Vukadinović, 1983).

The Yugoslav public paid a great deal of attention to the activities of the colonial powers. Of special interest was the liberation struggle fought by various anti-colonial movements. The news concerning the situation in Iran appeared in the Yugoslav press as early as the late autumn of 1944. Gradually, political vistas broadened to include Egypt, Syria and Lebanon all the way to China and Japan. The focus was on India and the Levant, but Indonesia, Vietnam (Indochina), Ethiopia, Iraq and Palestine were also of interest. From early on, the public learned about the likes of Nehru, Sukarno and Mao Zedong. Information given in the newspapers and on the radio was steeped in an ideology that guided the interpretation and evaluation of international events. The bulk of the information originated from the "Soviet sources" - telegraph agencies, radio stations and the press. From mid-1948 onward, the sources changed, but the interpretations remained the same. Political information dominated the discourse. News concerning the 
exploitation of natural resources and cheap labour, strikes, state terror, passive resistance, armed struggle, conservative regimes "tottering" under the onslaught of freedom, social justice, racial and class equality, the moral bankruptcy of wars fought by the colonial powers, a "wildfire" of anticolonial movements and revolutions - contributed to the emergence of a convincing and precisely defined (and disseminated) ideological view of colonialism. Divisions and conflicts reported in the media reflected a critique of the policy of spheres of interest, the division into blocs, armament race, technological boom, misuse of nuclear energy, all forms of exclusion and politics of force. Similar to the information fed to the public was the (ideologically coloured) information entering the country through diplomatic channels and the Party contacts from China (from 1945), Korea (1946), Iraq (1946), Lebanon (1946), Syria (1946), the Republic of South Africa (1946). The conflict with the Soviet Union compelled Yugoslavia to redefine its foreign policy. The Principles of the UN Charter were placed at the forefront of Yugoslavia's posture. Already viewed by the Yugoslav politicians as an upholder of peace, guarantor of the application of International Law and the platform for dialogue between the Cold War rivals, the OUN served as the sole forum for expressing their views. Although Yugoslavia had already held well-defined positions on numerous international questions, it was noticeable that it followed the Soviet lead and adapted its views to suit the policy of the "First Land of Socialism". This undoubtedly resulted from a "genuine commonality of interests" prompted by the ideological and political closeness to the Soviet Union as well as the acceptance of the Soviet experience and "solutions" in all spheres of life. In addition, international opinion was automatically polarised in line with the views of the Great Powers. The Friendship Treaty with the Soviet Union ratified in Moscow on 11 April 1945 ensured a common stance in the spirit of "sincerest cooperation in all international activities aimed at securing peace and security". Between 1945 and 1948, Yugoslav diplomacy occasionally acted independently on what was considered to be the crucial issues, notwithstanding moderate levels of engagement and superficial understanding of the functioning of the UN. Such acts were informed by the indigenous nature of the Yugoslav revolution, "own understanding and independent estimates" of the current situation. The specificity of the Yugoslav internal development and "independent spirit" was also coloured by "the repeated insistence on strengthening peace", independence, autonomy, sovereignty, equality and cooperation with all countries prepared to accept these principles (Jovanović, 1985, 1990, 2011; Dimić, Milošević et al. 2010; Dimić and Zivotić, 2012). Reduced diplomatic activity 
and pronounced agreement with the views of the Soviet delegation during 1948 reflected attempts to eliminate foreign policy differences. The approach Yugoslavia was forced to adopt following the clash with the Soviet Union and "Popular democracies" contained several important characteristics. It became realistic and pragmatic (making use of international divisions), elastic (rather than dogmatic), active (based on the understanding that small countries have their place in the international political arena) and cautious (predicting future outcomes, evaluating different scenarios and eliminating the element of surprise). The principles of the UN Charter were at the forefront of Yugoslav foreign policy. Differences with the Soviet Union not only brought into question the nature of the relations between socialist countries, but also offered a way forward for Yugoslav foreign policy. Following the decision by the Politburo of the Central Committee of the Communist Party of Yugoslavia (September 1949), the Yugoslav diplomats at the UN were to act independently, in the interest of the state and world peace (Jovanović, 1985; Rubinstein, 1970; AJ, CK SKJ, III/42 i 43, 1949). This new foreign policy stance became visible at the Fourth Session of the UN General Assembly in 1949 in which the Yugoslav side made public its dispute with the Soviet Union - receiving support from the majority of the members in the process. On this occasion, the Yugoslav delegates asked a question that would later serve as a basis for the policy of "peaceful coexistence". The question was: Is it possible for countries with different systems to coexist and cooperate peacefully, thus ensuring peace in the world? As a direct consequence, the Soviet Union abrogated the Friendship, Mutual Cooperation and Post-War Assistance Treaty and a Second Resolution of the Cominform was published two months later (29th November 1948). The Third Plenary Session of the Communist Party of Yugoslavia was held at the end of December 1949. These pressures were characterised as "Cold War tactics" used by the USSR against Yugoslavia, and the "battle for independence" fought by Yugoslavia as the "most important battle for socialism in the world" (Jovanović, 1985, pp. 45-46). From that point on, Yugoslavia voted in accordance with its international interests and convictions. This new policy was based on stressing the importance of small countries in world politics, opposing outside interference in domestic affairs and pointing out the dangers of military blocs (Jovanović, 1985, pp. 43-44; Dimić, Milošević et al. 2010, pp. 511-521, 524-531, 554-560; Kardelj, 1949; AJ, CK SKJ, II/7, 1949). One year later, Yugoslavia became a non-permanent member of the UN Security Council. Addressing the General Assembly, the Head of the Yugoslav delegation Edvard Kardelj rejected the imperative according to which, "(...) the only 
choice for Mankind is between the hegemonies of two Powers". As an alternative, he offered a "second way" to all free and equal nations - the way that leads to permanent peace through the establishment of democratic relations between nations, non-interference, striving for equality and comprehensive international cooperation. This new position signalled a toning-down of dogma-laden views of irreconcilable fronts and a life-anddeath struggle between conservatism and the forces of progress that had hitherto hampered Yugoslavia's international standing. Rejection of the politics of force and the risks of bloc alignment represented another premise of the new course. Yugoslavia saw this policy as a way of defending its endangered existence (at the UN, Yugoslavia was fighting a diplomatic battle for independence, territorial integrity and the right to selfdetermination), shape its own position vis-a-vis the crucial questions of world order and build a new international role. Such an approach meant abandoning the role of a "second-rate player" that necessarily befell small and economically and militarily weak countries. It indicated that Yugoslavia was now pursuing a mature policy based on the understanding of the broader political context. Speeches by Yugoslav delegates to the UN soon brought to light the outlines of a "new diplomatic course" which consisted in principled cooperation with all countries (irrespective of their system), struggle for world peace and a world of free and equal nations, as well as the opposition to any form of outside interference into domestic affairs (AJ, CK SKJ, III/54, 1951; Jovanović, 1985, pp. 85-89).

The Korean War brought about another change in the foreign policy of Yugoslavia. At the time the Korean War broke out, it became possible for Yugoslavia, as a member of the Security Council, to add a number of universally valid principles to a foreign policy hitherto marked by a high degree of tension provoked by the clash with the Cominform. These principles brought Yugoslavia closer to the countries such as India, Burma, Egypt and Indonesia and made possible common action with regard to important international issues. The commonality of views was reflected in the conviction that the polarisation of the world was pushing small and newly liberated countries towards neutrality. According to Tito, alignment with one of the sides meant "clearly endangering one's own country". The calls for the defence of peace, peaceful conflict resolution, abolition of artificial trade barriers and spheres of interest, rejection of all forms of aggression, as well as opposition to hegemony and outside interference and support for the natural and historic striving of the peoples of Asian and African countries to be free and independent - these were not just elements of an attractive foreign policy platform, but also a means of defending one's 
own independence. The superpower conflict and the developments within the UN made Yugoslavia, Burma, India, Egypt and Indonesia part of the same historical process. The journey from the vote against allowing the UN troops to cross the 38th Parallel in 1950, via first economic policy consultations, to permanent contacts maintained during the UN General Assembly Sessions, was a substantive one. It articulated resistance to the bloc-inspired polarisation of the world (Bogetić, 1981, 1990; Bekić, 1988; Gavranov and Stojković, 1972; Jovanović, 1985; Petković, 1985; Vukadinović, 1983; Rubinstein, 1970; Min, 2002; Vestad, 2009; Mates, 1970).

\section{Non-aligned politics and broadening the foreign policy perspective}

The first contacts Yugoslavia made at the UN led to the "broadening of the political perspectives" through which a Eurocentric policy was replaced by the forging of global links among the Non-Aligned countries. Such cooperation in the period from 1950 to 1951 stemmed from common views on the current international situation. It emerged from the unique positions of individual countries vis-a-vis various political questions. According to Tito (February 1952), the policy of "active neutrality" implied a struggle for peace and protest against aggressive wars and spheres of interest, opposition to all forms of outside interference into domestic affairs, maintenance of neighbourly relations and comprehensive development of peaceful economic, political and cultural cooperation on the basis of equality and mutual understanding. In this period, Yugoslav diplomacy acted continually at the Sessions of the UN General Assembly in accord with countries holding similar positions. At the Seventh Session held in 1952, the "non-engaged" countries raised the issue of underdevelopment and the urgent need to overcome it. The following year saw a demand for the establishment of an International Development Fund. In 1954, the focus was on colonialism. The Tenth Session (1955) highlighted the problems of disarmament. Joint interventions demonstrated the degree to which nonalignment was already built into the international doctrine of the countries of South-East Asia. Resisting pressures to join the blocs, seeking a peaceful resolution to conflicts with neighbours, fiercely protecting national sovereignty, a common position on decolonisation, opposition to racial discrimination, actively neutral posture, poverty and underdevelopment and non-alignment - all of these elements characterised the international stance of countries such as India, Burma, Indonesia and Ceylon. Similar developments took place in the Middle East and African countries such as Egypt, Syria (later the UAR) and Ethiopia as well as the states that gained 
independence in the second half of the 1950s - Algeria, Ghana, Guinea, the Congo and others (Jovanović, 1985, pp. 165-177, 223-235, 237-248). Beginning with 1952, the Yugoslav Press started to analyse the problems of Asian and African countries. At the end of 1952, Yugoslav diplomats were given strict directives to "strengthen contacts" with representatives from Asian and African countries. This coincided with the moment in which Yugoslavia, burdened by the relationship with the West, sought a new foreign policy direction. The brief foray into regional cooperation with Greece and Turkey (The Balkan Pact was formed in 1953 and became a military alliance in 1954) as well as the formulation of the policy of active neutrality opened the road for a new approach marked by Tito's journeys (of which there were seven: 1. Turkey, 12-18 April 1954; 2. Greece, 2-6 June 1954; India and Burma, 16 December 1954 - 5 February 1955, including the meeting with Nasser on board the yacht Galeb on 5 February 1955; 4. Ethiopia and Egypt 11 December 1955 - 6 January 1956; 5. The UAR, Indonesia, Burma, India, Ethiopia and Sudan, 5 December 1958 - 5 March 1959; 6. 15th Session of the UN General Assembly in New York; 7. Ghana, Togo, Liberia, Guinea, Mali, Morocco, Tunisia, Algeria and the UAR, 28 February - 22 April 1961). These trips represented the first opportunity for Yugoslavia to connect with countries that followed a similar foreign policy course. The crucial point was Titos's visit to India and Burma (Bogetić, 2005; Dimić, 2004). Addressing the members of the Indian Parliament on 21 December 1954, Tito pointed out the importance of coordinated international activity on the part of Yugoslavia and the countries of South-East Asia. Tito listed inequality, outside interference, spheres of interest and colonialism as the greatest "evils" faced by Mankind. He pronounced "active peaceful coexistence" to be the only path towards world peace. In his Rangoon speech, Tito contrasted attempts to bring the principle of coexistence to the regional level with the strategy of connecting and organising on a global scale. These two principles - regionalist and universalist - would clash often in years to come (Tito, 1959, 1955). At the end of his first journey, Tito realised that the quality of information gained through personal contacts represented political capital, which placed him ahead of other Communist leaders traditionally unwilling to travel. Visits, meetings, talks and exchanges of views became permanent features of Tito's and Yugoslavia's international strategy. Conflict mediation not only shaped the policy of peaceful coexistence but also ensured a role for Yugoslavia in global politics. Maintaining existing contacts was complemented by the deepening of newly forged ties. Yugoslavia's foreign policy posture was well-thought and carefully organised, leaving no room for improvisation. A hitherto remote and poorly 
understood part of the world became a subject of deep analysis and systematic study. This was based on a sound understanding of world politics and its principal protagonists. Yugoslavia constantly exchanged union, party, parliamentary, economic, youth, scientific, military, cultural and expert delegations with a large number of countries. The most capable and creative Yugoslav politicians travelled constantly to Africa and Asia, bringing back many impressions, information and ideas. Yugoslavia started sending its best diplomats to Africa and Asia (J. Djerdja, J. Vilfan, D. Kveder, V. Popovic, M. Nikezic, D. Vidic and others) and developing a highly professional press service which monitored the media, reviewed literature and provided a daily analysis of political and economic events. A special unit was formed within the Ministry of Foreign Affairs tasked with analysing the incoming information. Economic and Foreign policy institutes also contributed to a better understanding of the prevailing trends in world politics. Such an analytical approach yielded a truthful image of the "other". This required a sound understanding of both historical (studying the historical development and especially anti-colonial movements) and general facts (area, population density, social structure, institutions, geopolitical and geostrategic importance, political system, political, economic and cultural personalities). These two subjects made up $10-12 \%$ of the information gathered and analysed through diplomatic channels. The conclusions arrived were necessarily mutable and were continually updated with new information. Economic analysis, exchange of expertise, knowledge and technology transfer and the strengthening of economic ties meant that 20$25 \%$ of the information gathered by diplomats and correspondents concerned the economy. Political information, which involved analysis of internal and external circumstances with a focus on key underlying processes, comprised $50-60 \%$ of all collected information. All of this information was used in formulating optimal state interests. The result was a complex yet reliable picture of the "other" as well as of Yugoslavia's own interests. This represented a cognitive shift from a superficial (relying on perception and hearsay) to a deeper, scientific, level of understanding of foreign policy issues.

\section{The Bandung Conference}

Although Yugoslavia did not participate in the Asia-Africa Conference in Bandung (April 1955), the conclusions stated in the Final Communiqué were close if not identical to its position (AJ, KPR (837), I-4-e/1, 1970). The very fact that 24 countries with diverse systems and views gathered in one 
place was considered a success. In the opinion of Yugoslav diplomats, the most important result of the Conference was the principle according to which "(...) the right of all nations to individual and collective defence in accordance with the UN Charter should be respected". Another principle stated that "(...) countries should refrain from entering into collective defence arrangements which further interests of either Superpower" (AJ, KPR (837), I-4-e/1, 1970). The stress was placed on the solidarity between Asian and African countries in pursuing world peace as well as their common determination to "(...) decide their own fate and tackle their own problems" (AJ, KPR (837), I-4-e/1, 1970). The Bandung Conference was considered a crossroads in terms of awakening and bringing together of Asian and African nations as well as expressing the will for independence, belief in self-reliance and the increasing role in world politics. Importance was given to the agreement on furthering economic development based on mutual interest and respect for national sovereignty as well as the conviction that cultural cooperation represented one of the most powerful ways of furthering international understanding. These principles were followed by concrete demands for the improvement of cultural and educational cooperation through knowledge and information exchange, the revival of national cultures and rejection of all forms of cultural and racial discrimination. The unanimous condemnation of colonialism and discrimination and the proclamation of the principle of self-determination and freedom to choose a political and economic system were considered important victories. Branding colonialism as an evil that breaches fundamental human rights and that should be urgently eliminated fitted in with the Yugoslav policy of anti-colonialism. Condemnation of aggression, demands for universal disarmament and a ban on the production of nuclear and thermonuclear weapons were considered a great success. It was stressed that the Bandung Principles contributed to detente and created a platform for solving current issues through international cooperation based on equality. In Belgrade, the Bandung Conference was judged to represent a "historic crossroads" heralding a "new political landscape", the triumph of non-alignment and improvement in the global situation for Tito himself, the determination of the peoples of Asia and Africa to "decide their own fate as far as possible" was of primary importance. The same was true of the fact that "the conception dominating the Conference is in complete accord with our own" (AJ, KPR (837), I-4-e/1, 1970). The Principles of Bandung were confirmed in the meeting between Tito, Nehru and Nasser, held in July of 1956. The Joint Declaration insisted on the principle of "peaceful and active coexistence". Notable were demands for disarmament and acceptance of China into the UN. It was pointed out that the "...conflicting interests of 
Superpowers" hindered the resolution of the Middle Eastern conflict. It was concluded that the efforts of the Algerian people to gain independence should be supported. Colonialism was condemned in principle and the Bandung position vis-a-vis Palestine was endorsed. The meeting abounded in misunderstandings, difficulties in reconciling widely differing views, reserve and attempts to diminish its importance. Nevertheless, the Brioni Meeting contributed significantly to the convergence of Nehru's, Nasser's and Tito's views. The nationalisation of the Suez Canal and the ensuing Suez Crisis prompted Tito and Nehru to open regular channels of communication in order to coordinate views and act jointly in resolving the crisis. These were the outlines of the core of the movement personified by Nehru, Tito and Nasser (Mates, 1970, pp. 388, etc).

\section{Joint actions at the UN and preparations for the First Summit of Non-Aligned Countries}

The contacts between Tito, Nasser, Nkrumah and Nehru at the 15th Annual Session of the UN General Assembly (September 1960) were motivated by the conclusion that the superpowers were not capable of reaching a compromise with respect to the key issues of world peace. Presented in a separate resolution, "The Initiative of Five" represented an attempt by the Non-Aligned countries to mediate between the opposing Superpowers and their leaders. Even though it failed to gain sufficient support, the Resolution signalled future realignments in the UN, charted a course for the joint action by the Non-Aligned countries and contributed to the formation of close ties between countries with similar agendas. The "detente line" achieved a moral victory over the "politics of force". 41 countries voted for the Resolution and 37 US allies voted against it. 17 members close to the USSR abstained. The Non-Aligned countries started to view themselves as a positive, peaceful factor in world politics. The speeches by the above statements focussed on the issues of disarmament and colonisation to be followed by more trips, meetings and talks. One of the topics was the organisation of a conference of the Non-Aligned countries as well as placing their cooperation on a formal footing. The idea of a Non-Aligned summit to be held in Belgrade was taking shape (AJ, KPR (837), I-4-a, k-202, 1961; Mates, 1970). The obstruction of the work of the UN, which resulted from the superpower conflict added urgency to the need for a conference of the Non-Aligned countries. The conclusion that the superpowers and aligned countries were not capable of maintaining world peace and ensuring the running of the UN led to the idea that these tasks should become the responsi- 
bility of the numerically dominant Third World countries. In Tito's opinion, the first step towards strengthening their international clout would be a conference of the Non-Aligned states. The aim was to reach an agreement on important issues such as the preservation of peace, abolition of colonialism, disarmament, a ban on nuclear testing and the unobstructed work of the UN, before the 16th Annual Session of the UN General Assembly. An additional aim of the gathering was to formulate a common stance at the UN through which the Non-Aligned countries could contribute to the resolution of the crises directly imperilling world peace (DA, 1961, f-116, dos.1, dos. 2, dos 8; K41). Tito presented his views to some of the Non-Aligned leaders - King Hassan II, Prince Al-Hassan and President Bourguiba (AJ, KPR (837), I-2/13, 1961). ${ }^{2}$ They discussed how cooperation between all countries and peoples "regardless of their internal systems and ideological differences, and based on the principles of independence, equality and non-interference" could be achieved. Such important topics as the prevention of economic exploitation, the abolishment of colonialism and racial discrimination were also debated. In Tito's words, colonialism "was brought back to life" and it needed to be fully liquidated, as a precondition for bringing millions of people onto the world stage as "equal members of mankind", and as "progressive elements". Josip Broz especially emphasised the importance of equal participation of "all peoples, small and big alike" in the debates about world peace and the future of mankind. He also stressed the obligation of the international community and highly developed countries to help the newly independent states and ensure their economic and technological development. His stances were in line with the foreign political conceptions of other non-aligned countries. They all shared the view that the fates of newly liberated countries could not be determined by foreigners (AJ, KPR (837), I-4-a, k-202, 1961; AJ, KPR (837), I$2 / 13,1961)$. At a meeting held at the same time, Nasser gave his support to the need to organise a Conference of Heads of State or Government of NonAligned Countries and reach a common position on all key issues. The diplomatic push was immediately joined by the President of Indonesia Sukarno, the governments of Afghanistan and Ghana, and after some equivocation, by the Prime Minister of India Nehru. This opened the way to a gathering of representatives of the Non-Aligned countries on a global scale (DA, 1961, f-116, dos.1, dos. 3, dos. 5). Already in March, Yugoslav diplomats were aware that the Indonesian Government attempted to organise a new

${ }^{2}$ Between 28 February 1961 and 22 April 1961 Josip Broz Tito visited Ghana, Togo, Liberia, Guinea, Mali, Morocco, Tunisia, and the United Arab Republic. 
"Bandung Conference". Sukarno's envoys had visited Cambodia, Burma, Ceylon, the UAR, and Sudan, as he was convinced that the new Afro-Asian conference had to take place before the XVI Plenary Meeting of the UN General Assembly. In Sukarno's mind, Yugoslavia was the ideal venue for convening the conference of independent countries, which was to be dedicated primarily to the issue of Algeria (DA, K-15, 1961). ${ }^{3}$

During the months which preceded the Belgrade Conference, Yugoslav diplomats attempted to neutralise Indian diplomatic initiatives. Delhi's "conservative", "pro-western", and "opportunistic" stances differed radically from the views of African countries (Ghana, Guinea, and Mali) and Cuba. As the host, Yugoslavia attempted to avoid unnecessary and embarrassing quarrels at the Conference. Especially important were the drafts of the Final Document, as India demanded there be as few as possible binding clauses, especially those which targeted any of the great powers, whereas the more radical participants demanded sharp and condemning formulations. Belgrade also attempted to disprove the rumours that the Third bloc was about to be created (DA, 1961, f-117, dos. 15). In July of 1961, Tito and Nehru exchanged letters in which Nehru demanded assurances that no such initiative would take place. In his response, Tito stated that the creation of the Third block would be "opposite to our understanding of the policy of non-engagement" (AJ, KPR (837), I-1/374, 1961; DA, 1961, f-117, dos. 27, dos. 20). Tito also expressed the wish to cooperate with Nehru closely in the organisation of the Conference and seconded his opinion that the nonengaged were incapable of solving existing world problems, but that they could contribute to the lessening of world tensions (DA, 1961, f-117, dos. 25). After a short deliberation, both the Prime Minister of India and the governments of Afghanistan and Ghana confirmed their participation at the forthcoming conference. The universal doctrine triumphed over the regional one. The Preparatory Meeting held in Cairo in June 1961 represented an important step in that direction. ${ }^{4}$ There, a common policy core was

${ }^{3}$ In January of 1961, Sukarno came up with the idea of convening a summit of the non-aligned, devoted solely to the situation in Algeria. Koča Popović considered such a meeting useless, as he believed that neither Nehru nor U Nu would accept to participate in it. However, he advised that the reply to the Indonesians be balanced, before other countries' stances were checked.

${ }^{4}$ The following states participated in the Preparatory Meeting in Cairo: Afghanistan, Cuba, Guinea, Indonesia, Mali, Saudi Arabia, the UAR, Yugoslavia, Morocco, Cambodia, Yemen, India, Nepal, Burma, Ceylon, Ethiopia, Sudan, Iraq, Somalia, Brazil (observer). 
formulated vis-a-vis international issues. The principal goal of the Conference was, in Yugoslav eyes, "to emphasise the positive effects of the non-engaged on the lessening of world tensions". Belgrade claimed that the non-engaged were "neither against the West nor the East", and that they "refused to acknowledge such [bipolar] criteria". Yugoslavs admitted that the principled anti-colonialism "could be seen as anti-western", but insisted that "it should not be interpreted as taking the other side". Similar stances should be taken on other major international issues as well (DA, 1961, dos. 25).

The great powers were highly interested in the forthcoming conference of the non-aligned. American diplomats attempted to leave an impression of the US affinity towards the conference, should the participants abstain from condemning imperialism. Internal American analyses reveal their conviction that Yugoslavia, despite being led by "convinced Marxists", would not sacrifice its independence. Nevertheless, they were troubled by the fact that Belgrade expressed rather pro-Soviet stances on the most international issues. The rapidly increasing Yugoslav influence on other non-engaged countries did not fly under the radar of American intelligence analysts. They were aware of Yugoslav endeavours to position itself as the leader within the Afro-Asian flock and to establish contacts with Latin American countries. On the other hand, London attempted to downplay the importance of the Conference, as they were uneasy with the anti-colonial rhetoric. The Yugoslavs assessed that the UK would not be passive and that they would attempt to further the existing divides between the participants in order to prevent any meaningful conclusions. The British were especially concerned about the possibility of the emergence of a Third bloc. The Soviet diplomats, on the other hand, praised the Conference as a great and useful initiative, but attempted to influence its outcome and support anti-western resolutions. Moscow did not approve of the non-engagement as a principle because it hindered the "grouping of progressive forces around the Soviet Union", and decreased Soviet influence among the newly liberated countries. The Eastern Bloc countries even proposed to the Yugoslavs to coordinate foreign policies towards African and Asian countries (DA, K-41, 1961; DA, 1961, f-117, dos. 1). On the other hand, Beijing was convinced that the aim of the Belgrade Conference was to divide the Asian peoples. The western media took a wait-and-see approach (DA, f-116, dos. 17, dos. 1, dos. 36, dos. 23, dos. 34; Pavlović, 2009, pp. 217, etc.). The agreed criteria used in selecting the Conference participants defined the essence of Non-Alignment. Belgrade was chosen to be the host city by the majority of participants. Bandung, Brioni, New York and Cairo represented important signposts to the Belgrade Conference. During that time, views on international issues 
matured, aims and principles were formulated and Yugoslavia's international position was defined. This position informed the proposals put forward by the Yugoslav delegation at the Belgrade Conference.

\section{Decolonisation and Yugoslav foreign policy}

The process of decolonisation which gained momentum at the beginning of the 1960s had a strong impact on Yugoslavia's foreign policy through a number of universal premises (AJ, KPR (837), 1961). The demand for immediate and comprehensive decolonisation brought Yugoslavia closer to the newly liberated countries of Africa and Asia and enabled a coordinated international activity on their part. Submission to foreign domination and exploitation was deemed to represent "abnegation of basic human rights" and the primary obstacle to international peace and cooperation. The right to self-determination was demanded enabling them to decide freely on the form of political system they would adopt as well as the direction of their development. Cessation of military interventions and repression by the colonial powers was considered a necessity. It was demanded that the power be immediately handed over to subjugated nations so that they could enjoy the fruits of freedom and independence. Any possibility of endangering the territorial unity and integrity of these new nations was rejected a priori. Yugoslav politicians were of the opinion that these goals necessitated strengthening "independent and non-engaged forces" and arrive at a blueprint for the permanent dismantling of power blocs. Until such time, it was important to detach the process of decolonisation from the Cold War and prevent the countries in Asia and Africa from becoming entangled in the superpower contest. Consequently, attention was directed towards tackling the current crisis hotspots. The UN General Assembly was deemed responsible for overseeing the process of decolonisation in order to "ensure the transfer of power to the hands of genuine representatives of the people" (AJ, KPR (837), 1961). Decolonisation revealed the tragic chasm between the developed and underdeveloped parts of the world and highlighted the question of the future direction. Yugoslav politicians thought that the economic policies of the developed countries were tainted by the exigencies of the Cold War, resulting in the transformation of military blocs into closed economic groupings. The danger of the Cold War spilling over into the economic arena was reflected in the conditions attached to aid which required access to domestic markets, profit export, and demands for changes in the political systems. The conclusion was that the economic backwardness represented a permanent source of international instability and a generator 
of new conflicts. In addition, inequalities in economic development precluded active and equitable cooperation and, consequently, world peace and stability. For these problems to be resolved, economic aid had to become an international obligation, especially for the industrially developed countries. The levelling of inequalities necessitated an increase in long-term aid which in turn would enable accelerated development, decoupling economic aid from political and military demands through a clear definition of conditions for receiving international development grants and an awareness that new political relationships required new economic relationships. Those same problems raised the awareness of common interests and the need for joint action in overcoming poverty (AJ, KPR (837), 1961).

\section{Attitudes towards the issue of disarmament and the Berlin crisis}

With regard to the problem of disarmament, Yugoslavia's view was that a new approach to negotiations was necessary. As opposed to the zero-sum game approach adopted by the Great Powers, it demanded that disarmament talks be joined by the entire international community and especially by the Non-Aligned countries. General, comprehensive and monitored disarmament was considered the ultimate aim (AJ, KPR (837), 1961). Until this was achieved, freezing of arms budgets, stopping the arms race and nuclear test ban treaties were considered the more realistic steps. The alternative was the continuation of the propaganda war, the spread of hopelessness and fear and the ability of the great powers to hijack the international discourse for their own selfish ends. The crisis over Berlin and Germany was another sensitive issue directly related to the issues of disarmament, bloc confrontation, and world peace. The Yugoslavs were aware that Berlin and Germany were not of primary importance for the most African and Asian countries. However, they insisted on treating these problems as global and not regional European issues. They further believed that East and West alone were incapable of solving the German Question peacefully and that the non-aligned could contribute to regulating the "abnormal" situation in the German capital, and normalising the international situation (AJ, KPR (837), 1961).

\section{The First Conference of Non-Aligned Countries in Belgrade and open world issues}

In mid-August, the Yugoslav Foreign Ministry once again gave instructions to the diplomats throughout the non-bloc world in order to 
ensure the Conference's success. The instructions clearly defined the main aim of the Conference: "lessening of tensions between East and West, and in the world in general". Yugoslav diplomats were therefore supposed to suggest to the conference participants' governments that their approach to international problems should be "realistic and objective, i.e. balanced and constructive, and supportive towards all positive tendencies and stances" (DA, 1961, f-117, dos. 29). In this way, the Yugoslavs attempted to prevent expressions of radicalism and extremism, and to avoid "open critique of negative tendencies and acts in international relations". The conference participants should be guided by the interests of world peace. Their approach to international problems should not be determined by concerns whether the conference would appear as East- or West-leaning. Yugoslav diplomats predicted that the conference participants would be united with regards to the "issue of colonialism" and in their condemnation of "neocolonialism" (especially in their assessment of the situation in Algeria, Congo, Angola, West Irian, Tunisia, Goa, and racial discrimination in the Republic of South Africa), as well as in exerting moral and political pressure on the great powers to reduce nuclear weapons. Furthermore, the necessity to change the existing economic gap between developed and developing countries was also deemed uncontroversial (DA, 1961, f-117, dos. 29). At the time of the Belgrade Conference, the Cold War was in full swing. The superpower confrontation over Berlin resulted in the construction of the Berlin Wall. The Cuban Missile Crisis brought the world to the brink of nuclear war. Peace was threatened by the colonial and Superpower interventions in the Congo, Angola, Vietnam and Laos. The nuclear moratorium was disregarded. All of these issues tested the statesmanship of the politicians gathered in Belgrade.

"We have gathered here today in order to coordinate our efforts to help the world, which is constantly being pushed towards the brink, to see at this late hour the danger it faces, to invest its moral strength and energy in strengthening peace and furthering a comprehensive and equitable international cooperation." With these words from his opening speech of 1 September 1961, Josip Broz Tito greeted the delegates from 25 participating countries, three observer countries and 40 liberation and progressive movements. His political convictions were shared by the likes of Nehru, Nasser, Sukarno, Nkrumah, Sihanouk, Makarios, Selassie, U Nu, Bourguiba, Sirimavo Bandaranaike, Keita and other statesmen attending the conference from Asia, Africa, South America and Europe. The Conference agenda proposed an exchange of views regarding the world situation, strengthening 
of world peace and security and the problems of economic inequality and underdevelopment (AJ, KPR (837), 1961).

The Heads of State or Government of Non-Aligned countries were in complete agreement that world peace could only be achieved with complete eradication of colonialism, imperialism and neocolonialism "in all their forms". They brooded over the realisation that the superpower rivalry could lead to a "global conflagration". Peaceful coexistence which involved an active effort in removing historical injustices and subjugation and encouraging individual development was seen as the only alternative to the Cold War and a sound platform for international relations. They condemned the politics of force and the armament race. War was considered not only an anachronism, but a crime against humanity. They rejected the view that the Cold War was unavoidable as well as the policy of permanent racketing up of the tension which had brought the world to the brink of a global war. Differences in the social organisation were not viewed as an insurmountable obstacle to international cooperation. The imposition of political systems by force was considered unacceptable. They rejected outside domination and interference and supported self-determination, independence and free choice of modes of economic, cultural and social development. They believed that the conduct of the foreign policy should shun ideology as a weapon for waging a Cold War, exerting pressure and imposing one's will. They insisted on responsibility, realism and a constructive approach to world politics. They indignantly rejected accusations that one of the aims of the Belgrade Conference was the creation of a new bloc. They believed that Non-Aligned countries should play a major role in world politics. Population growth was seen as a significant contributor to the process of "narrowing the gap between the blocs" (AJ, KPR (837), 1961).

\section{Results of the Belgrade Conference}

The Belgrade Conference adopted two documents: A Declaration by Heads of State or Government of Non-Aligned Countries and a Statement Concerning the Danger of War and an Appeal for Peace. At the same time, copies of an identical letter were sent to President Kennedy and Premier Khrushchev. In contrast to the Declaration, which had a strategic character, the other two documents referred to the current political situation (AJ, KPR (837), 1961). Pointing out acute problems the world was facing, the Declaration insisted on an unconditional, complete and final abolition of all forms of colonialism, neocolonialism and imperialism. Cessation of military actions 
and repression against "...dependent nations" as well as their right to independence and respect for their state territory were considered important. Wholehearted support was given to the national liberation struggle of the peoples of Algeria and Angola against French and Belgian colonial forces. Solidarity with the people of the Congo and the condemnation of the Belgian intervention were expressed equally strongly. The French massacre in Bizerte (Tunisia) directly influenced the demand for the withdrawal of foreign troops from all "dependent" countries. The policy of Apartheid in South Africa and other forms of racial discrimination were condemned unanimously. Support was given to the right of ethnic and religious minorities to protection, especially against genocide. Wholehearted support was also given to the people of Palestine. The building of foreign military bases, especially against the will of the people, was considered a gross violation of sovereignty. Disarmament was considered an "imperative and the most urgent task facing humanity". The economic inequality inherited from the age of colonialism and imperialism was to be eliminated and the economic, industrial and horticultural development accelerated. Developing countries were advised to increase their economic and trade cooperation. A separate World Economic Conference dedicated to the issue of underdevelopment was deemed necessary. The Declaration reaffirmed the deep conviction of the delegates that all nations had the right to independence and self-determination (AJ, KPR (837), 1961). The Belgrade Conference agenda covered all the important international questions. The participants exhibited a high degree of agreement (AJ, KPR (837), 1961). At the same time, debates on various issues clearly indicated the presence of divisions and differences. Besides, the advocates of pro-Soviet policies and those who were not ready to criticise the West, there existed countries that lacked well-formed views on international issues. Subsequent analyses by Yugoslav politicians revealed the existence of an "Arab faction" which focussed on "Arab demands". The West labelled the Belgrade Conference an anti-Western and anti-American gathering (DA, 1961, f-118, dos. 9, dos 12; DA, 1961, f-125, dos. 12; AJ, KPR (837), 1961). The reactions were heated and inimical. Moscow reacted by restarting nuclear tests. The Conference was ignored by the Soviet and Eastern European public (AJ, KPR (837), 1961). Nevertheless, the reverberations of the summit as well as the worldwide publicity it received exceeded expectations. The Yugoslav leadership assessed the Conference to be a "major event" which signalled the "victory of the Yugoslav conception" which put paid to the regionalist strategy calling for a "second Bandung".

The Non-Aligned movement was not born in Belgrade. The gathering of the Heads of State or Government of Non-Aligned Countries did not 
necessarily imply a movement. Nevertheless, the decisions reached in Belgrade clearly demonstrated that the idea which had brought these statesmen together represented an alternative to power blocs and the world polarisation. The frequently spoken words at that time, such as "peace", "independence", "equality", "development", "law" and "justice", resonated in the minds of the peoples who had for centuries existed on the margins of history and which were trying, through anti-colonial struggle, to ascend the ladder of global power. In 1961, Non-Alignment seemed like a "policy with a future".

\section{References}

Bekić, Darko. (1988). Jugoslavija u Hladnom ratu, Zagreb, Globus.

Bogetić, Dragan (1990). Koreni jugoslovenskog opredeljenja za nesvrstanost. Beograd

Bogetić, Dragan. (2000). Jugoslavija i Zapad, Beograd, Službeni list.

Bogetić, Dragan. (2005). „Titovo putovanje u Indiju i Burmu i oblikovanje jugoslovenske politike nesvrstanosti“', Istorija 20. veka, 2.

Bogetić, Olivera, Bogetić, Dragan. (1981). Nastanak i razvoj pokreta nesurstanosti. Beograd, Export Press.

Dimić, Ljubodrag, Milošević Miladin et. al. (2010). Jugoslovensko-sovjetski odnosi 1945-1956. Zbornik dokumenata. Beograd, MSP.

Dimić, Ljubodrag, Životić, Aleksandar. (2012). Napukli monolit. Tematska zbirka dokumenata, Beograd, Arhipelag.

Dimić, Ljubodrag. (2004).,,Titovo putovanje u Indiju i Burmu 1954-1955, Prilog istoriji Hladnog rata", Tokovi istorije, 3-4.

Gavranov, Velibor, Stojković, Momir. (1972). Medunarodni odnosi i spoljna politika Jugoslavije, Beograd, Savremena administracija.

Jakovina, Tvrtko. (2002). Socijalizam na američkoj pšenici, Zagreb, Matica hrvatska.

Jovanović, Jadranka. (1985). Jugoslavija u OUN (1945-1953), Beograd, ISI.

Jovanović, Jadranka. (1990). Jugoslavija i Savet bezbednosti 1945-1985, Beograd, ISI.

Kardelj, Edvard. (1950). „Spoljna politika FNRJ, Treći plenum CK KPJ (29_ 30. 12. 1949)“, Partijska izgradnja, 2.

Krempton, Ričard Dž. (2003). Balkan posle Drugog svetskog rata, Beograd, Polis. 
Laker, Volter. (1990). Istorija Evrope, 1945-1990, Beograd, Clio.

Mates, Leo (1970). Nesvrstanost - teorija i savremena praksa. Beograd, IMPP.

Min, Kim Čol. (2002). Jugoslavija i Korejski rat, PhD thesis, Beograd, Filozofski fakultet.

Pavlović, Momčilo. (2009). „Nacionalna obaveštajna procena - Izgledi Jugoslavije (NEI 15 - 61) od 23.maja 1961“, u: Dokumenti CIA o Jugoslaviji 1948-1983, Beograd 2009.

Pavlović, V. G. (2011). The Balkans in the Cold War, Belgrade, Institute for Balkan Studies of the Serbian Academy of Sciences and Arts.

Petković, Ranko. (1985). Nesvrstana Jugoslavija i spoljni svet. Spoljna politika Jugoslavije 1945-1985, Zagreb, Školska knjiga.

Rubinstein, Alvin. (1970). Yugoslavia and the Nonaligned World, Princeton, University Press.

Tito, J.B. (1955). „Govor J.B. Tita na Rangunskom univerzitetu prilikom proglašenja za počasnog doktora prava 16. Januara $1955 "$, u: Govori $i$ članci, X, Zagreb, str. 60-67.

Tito, J.B. (1959). „Govor J. B. Tita u indijskom Parlamentu 21.decembar 1954 “, u: Govori i članci, X, Zagreb, str. 23-33.

Tito, J.B. (1959). “Osvrt na neke aktuelne međunarodne probleme”, u: Govori $i$ članci, XI, Zagreb, str. 423-434.

Tito, J.B. (1962). „Govor na univerzitetu u Bandungu prilikom dodjeljivanja počasnog doktorata, Bandung, 26. 12. 1958", u: Govori i članci, XIV, Zagreb, str. 17-44.

Vestad, Od Arne. (2009). Globalni hladni rat, Beograd, Arhipelag.

Vukadinović, Radovan. (1983). Hladni rat i Evropa, Zagreb, Augus Cesarec.

Arhiv Jugoslavije (AJ) [Archives of Yugoslavia]. Kabinet Predsednika Republike [Cabinet of the President of the Republic], KPR, 837, I-4-a, k202/Prva konferencija nesvrstanih zemalja: Govor druga Predsednika na Petnaestom zasedanju Generalne skupštine Ujedinjenih nacija, Njujork, 22.9.1960; Iz govora druga Predsednika na mitingu po povratku sa generalne skupštine Ujedinjenih nacija, Njujork, 12.10.1960; Iz ekspozea druga Predsednika održanog u Saveznoj narodnoj skupštini, Beograd, 26.12.1960; Iz govora druga Predsednika održanog po povratku sa puta po povratku sa puta po zemljama Zapadne i Severne Afrike, Beograd 27.4.1961; KPR (837), I-4-e/1, Završni kominike Bandunške konferencije; Ocena Azijsko-africke konferencije u Bandungu; KPR (837), I-4-a, k-202, Govor J.B. Tita na Petnaestom zasedanju Generalne skupštine UN održane u Njujorku 22. septembra 1961; Iz govora druga 
Predsednika na mitingu u Beogradu po pooratku sa Generalne skupštine Ujedinjenih nacija u Njujorku, 12.oktobra 1960; Iz ekspozea druga Predsednika održanog u Saveznoj narodnoj skupštini 26.12.1960; KPR (837), I-2/13, Zajedničko saopštenje povodom zvanične posete J.B. Tita Republici Gani od 4.3.1961; Zajedničko saopštenje povodom posete J.B. Tita Republici Gvineji od 21-24.3.1961; Zajedničko saopštenje povodom posete J.B. Tita Republici Mali od 25-26.3.1961; KPR (837), I-4-a, k-202, Proa konferencija nesvrstanih zemalja, Govor druga Predsednika u Parlamentu Gane, Akra, 2.3.1961; Govor druga Predsednika u Parlamentu Tunisa, Tunis, 10.4.1961; Iz govora druga predsednika održanog u Beogradu po povratku sa puta po zemljama Zapadne i Severne Afrike, Beograd, 27.4.1961; Izveštaj Predsednika republike o putu Jugoslovenske delegacije u prijateljske zemlje Zapadne i Severne Afrike podnet na sednici SIV-a od 29.4.1961; KPR (837), I-2/13, Materijali i dokumenti o posetama druga Predsednika afričkim zemljama, februar - april 1961; KPR (837), I- 1/374, Poruka Dž. Nehrua J.B. Titu od 23.jula 1961; KPR (837), I-4-a, k-204/ Kolonijalizam, materijal za Beogradsku konferenciju; KPR (837), I-4-a, k-204/ Razoružanje, materijal za Beogradsku konferenciju; KPR (837), I-4-a, k-204/ Nemačka i Berlin, materijal za Beogradsku konferenciju; KPR (837), I-4-a/k202, Pozdravni govor predsednika Tita od 1. 9. 1961; KPR (837), I-4-a, Pregled istupanja šefova delegacija na Konferenciji proog dana zasedanja, 1. septembar 1961; Pregled istupanja šefova delegacija na Konferenciji drugog dana zasedanja, 2. septembar 1961; Pregled istupanja šefova delegacija na Konferenciji trećeg dana zasedanja, 3.septembar 1961; KPR (837), I-4-a/ Beogradska konferencija, Izjava o opasnosti od rata i apel za mir; Pismo Hruščou i Kenediju; Deklaracija šefova država i vlada vanblokovskih zemalja; KPR (837), I-2/14, Zapisnici sa razgovora izmedu Predsednika Tita i Predsednika Nasera od 18. 11. 1961. (pre i posle podne); KPR (837), I-5-b/SAD, Zabeleška o razgovoru druga L. Matesa sa ambasadorom SAD G. Kenanom, 15.9.1961. u 12h;, KPR (837), I-5.b/SAD, Zabeleška o razgovoru potpredsednika Saveznog izvršnog veća Mijalka Todorovića sa ambasadorom SAD g. Kennanom od 11. 10. 1961; KPR (837), I-1/991, Poruka predsednika FNRJ Josipa Broza Tita predsedniku Saveta ministara SSSR-a Hruščovu u vezi sa objavljivanjem odluke Vlade SSSR-a o nastavljanju nuklearnih proba, 16. 9. 1961; KPR (837), I-1/1294, Pismo J.B. Tita upućeno učesnicima Konferencije šefova država i vlada neangažovanih zemalja, 18. 9. 1961; KPR (837), I-1/991, Odgovor N.S. Hruščova upućen J.B. Titu 27. 9. 1961; CK SKJ, III/42 i 43. Zapisnici sa sednica CK SKJ od 30. avgusta 1949. i 7. septembra 1949; Govor E. Kardelja; CK SKJ, III/54, Izveštaj E. Kardelja sa V zasedanja Generalne skupštine OUN; Govor E. Kardelja u OUN od 30. 10. 1951, Govori članova naše delegacije na V zasedanju OUN, Beograd 1951. 
Diplomatski arhiv Ministarstva spoljnih poslova Republike Srbije (DA MSP RS) [Diplomatic archive of the Ministry of Foreign Affairs of the Republic of Serbia]: 1961, PA, f-116, dos.1, br. 45196. Telegram ambasadora D. Kvedera iz Delhija od 17.2.1961; 1961, PA, 1961, f-116, dos. 2, br. 49237. Telegram J. Đerđe ambasadoru jugoslovenske države u Indoneziji Pavliću od 25.3.1961; 1961, PA, f-116, dos. 8, br. 410166. Telegram ambasadora Pavliča iz Džakarte od 1.4.1961; 1961, K-41, Kabinet Koče Popovića, strogo poverljivo, Zabeleška od 25.2.1961; K-15, f-2, Kabinet Koče Popovića, strogo poverljivo 2.2.1961; K-41, Kabinet Koče Popovića, strogo poverljivo, Zabeleška od 25.2.1961; 1961, PA, f-116, dos.1, br. 45196. Telegram D. Kvedera iz Delhija od 17.2.1961; 1961, PA, f-116, Dos. 3, br. 49399. Telegram ambasadora R. Dugonjića iz Kaira od 27.3.1961; 1961, PA, 1961, f-116, Dos.3, br.49726; 1961, PA, 1961, f-116, Dos. 5, br. 410063; 1961, PA, 1961, f-116, Dos.3, br. 49596. Josip Đerđa ambasadama FNRJ u Rangunu, Kolombu, Kabulu, Kartumu, Adis Abebi, Pnon Penu od 29.3.1961; 1961, PA, f-116, dos. 3, br. 49695. Uputstvo J. Đerde ambasadoru u Akri od 30.3.1961; 1961, PA, f116, Dos. 7, br. 49515. Telegram J.Đerđe - V. Mićunoviću od 29.3.1961; 1961, PA, f-117, dos. 15, br. 421996. Telegram ambasadora D. Kvedera iz Delhija od 13.7.1961; 1961, PA, f-117, dos. 20, br. 422918. Telegram ambasadora D.Kvedera iz Delhija od 25. jula 1961; PA, f-117, dos. 27, br. 423782. Poruka J.B. Tita Dž. Nehruu od 28.jula 1961; 1961, PA, f-117, dos. 25, br. 423517, Telegram ambasadora D. Kvedera iz Delhija od 30.jula 1961; 1961, PA, Dos. 23, br. 415925. Cirkularni telegram ministra K. Popovića upućen diplomatskim predstavništvima FNRJ od 23.5.1961; 1961, PA, f-117, dos. 1, br. 415784. Telegram ambasadora Price iz Londona od 26. maja 1961; 1961, PA, f-116, dos. 17, br. 414750 i 415082. Telegrami D. Kvedera iz Delhija od 13.5.1961. i 15.5.1961; 1961, PA, f-117, Dos. 1, br. 415750. Telegram ambasadora S. Price iz Londona od 19.5.1961; 1961, PA, 1961, f-116, Dos. 36, br. 415811. Cirkularni telegram J. Đerđe - Svim predstavništima FNRJ od 22.5.1961;1961, PA, 1961, Dos. 23, br. 415925. Cirkularni telegram ministra K. Popovića upućen diplomatskim predstavništvima FNRJ od 23.5.1961; 1961, PA, f-116, Dos. 34, br. 416790, Telegram iz Pekinga od 25.5.1961; 1961, PA, f-117, dos. 29, br. 424464. Državni sekretarijat inostranih poslova ambasadama FNRJ u UAR, Indiji, Maroku, Gani...od 10.8.1961; 1961, PA, f-118, dos. 9, br. 427807. Odgovor Džona Kenedija upućen dr Sukarnu, predsedniku Indonezije 13.9.1961; 1961, PA, 1961, f-125, dos. 12, br. 428481. Telegram M. Nikezića iz Vašingtona od 21.9.1961; 1961, PA, f- 125, dos. 12, br. 428569. Telegram M. Nikezića iz Vašingtona od 23.9.1961; 1961, PA, 1961, f-118, dos. 12, br. 430010. Telegram Nikezića iz Vašingtona od 7.10.1961. 